\title{
Marta Cholewa-Wiktor
}

\section{Internetowe zasoby informacji a decyzje klientów usług medycznych}

Kody JEL: I11, I12

Słowa kluczowe: internetowe zasoby informacyjne, usługi medyczne, decyzje zakupowe pacjentów

Streszczenie. Media społecznościowe coraz silniej oddziałują na decyzje użytkowników, także w zakresie wyboru świadczeniodawcy usług medycznych. Uczestnicy grup społecznościowych czy dyskusyjnych, wymieniając się poglądami i doświadczeniami, wykorzystują efekt word of mouth, czyli polecenie innym internautom usług czy konkretnych osób na zasadach marketingu wirusowego. Ponadto użytkownicy sieci mają wpływ na kreowanie wizerunku gabinetu oraz lekarza poprzez oceny na profilach, takich jak Znanylekarz.pl czy Rankinglekarzy.pl. Celem artykułu jest przedstawienie wyników badań dotyczących wpływu informacji dostępnych w sieci na decyzje zakupu usług medycznych. Badania przeprowadzono wśród pacjentów zakładów opieki zdrowotnej z terenu Lublina i wykorzystano w nich samodzielnie opracowany kwestionariusz ankiety. Analiza uzyskanych wyników pozwala na stwierdzenie, że opinie innych użytkowników internetu wpływają na decyzje zakupowe pacjentów, ponieważ ponad $80 \%$ badanych chociaż raz dokonała wyboru świadczeniodawcy korzystając z informacji uzyskanych w sieci. 


\section{Wprowadzenie}

Zapotrzebowanie na usługi zdrowotne w Polsce stale wzrasta. Ten trend utrzymuje się mimo rozwoju profilaktyki zdrowotnej oraz wiedzy i technologii w zakresie samego leczenia. Sytuację tę warunkuje wiele czynników, np. tendencje demograficzne, dostępność usług zdrowotnych czy wreszcie wzrost świadomości pacjentów. Bezsporny jest również fakt, że potrzeby zdrowotne społeczeństwa przekraczają możliwości finansowania ich przez państwo (Paszkowska, 2010, s. 92). Rezultatem tego jest znacząca dysproporcja między popytem a podażą usług zdrowotnych. $Z$ drugiej zaś strony można zaobserwować znaczący wzrost oczekiwań pacjentów wobec usługodawców. Pacjenci coraz częściej zwracają uwagę na jakość oferowanych świadczeń, standard obsługi czy rodzaj użytej aparatury. W związku z tym częściej niż dotychczas na podstawie konkretnych kryteriów wybierają świadomie świadczeniodawcę usługi medycznej.

Kolejnym trendem, który można wyraźnie zaobserwować w obecnych czasach, jest stały wzrost znaczenia internetu w życiu niemal każdego człowieka. Internet wkracza we wszystkie sfery aktywności, np. zdobywania wiedzy i nauki, rozrywki, zakupów itp. Coraz częściej spełnia on także rolę miejsca, w którym nawiązywane są relacje interpersonalne, w dużej mierze zastępujące kontakty osobiste. W ostatnich latach można zauważyć szczególnie dużą aktywność użytkowników sieci w różnego rodzaju społecznościach wirtualnych. Relacje takie nawiązywane są z różnych powodów, nierzadko związanych również ze zdrowiem. Użytkownicy sieci poszukują informacji czy też rekomendacji innych na temat usług oraz ich świadczeniodawców. Media społecznościowe, w których użytkownicy prowadzą wymianę doświadczeń czy informacji mogą mieć więc znaczenie w decyzjach zakupowych.

Celem artykułu jest identyfikacja wpływu informacji dostępnych w sieci na decyzje zakupu usług medycznych. Aby zrealizować postawiony cel, przeprowadzono badania oparte na samodzielnie opracowanym kwestionariuszu ankiety.

\section{Proces podejmowania decyzji zakupowej usługi medycznej}

W literaturze przedmiotu istnieje wiele interpretacji pojęcia podejmowania decyzji. Niemniej jednak niezależnie od autora można zauważyć, że podejmowanie decyzji nie jest domeną danej chwili, ale jest złożonym procesem wymagającym uwzględnienia wielu czynników. W przypadku usług medycznych analiza ta jest tym bardziej konieczna, że pacjenci powierzają świadczeniodawcom swoje najwyższe dobro, jakim jest zdrowie i życie (wyjątek stanowią stany nagłe, np. wypadek, 
w których pacjent podejmuje leczenie w trybie natychmiastowym, zazwyczaj bez głębszego zastanowienia się nad wyborem świadczeniodawcy).

Tradycyjny model dotyczący decyzji zakupowych składa się z pięciu występujących kolejno po sobie etapów: rozpoznanie problemu, wyszukiwanie informacji, ocena alternatywnych rozwiązań, decyzja o zakupie i zachowanie pozakupowe (Rudnicki, 2000, s. 197). Warto jednak zaznaczyć, że nie jest to stały schemat postępowania, gdyż proces podejmowania decyzji może przebiegać w różny sposób, w zależności od wielu czynników: zarówno tych zewnętrznych, np. otoczenie i jego wpływy, jak i wewnętrznych, dotyczących samej osoby decydenta, np. jego przekonań, wartości, potrzeb, które wpływają na odbiór czynników płynących z otoczenia. Model pięcioetapowy zakłada także, że wymienione elementy mogą, ale nie muszą występować kolejno po sobie, bowiem pacjent może omijać niektóre etapy lub do nich wracać. Niemniej jednak wyraźnie pokazuje, że zakup usługi zdrowotnej rozpoczyna się dużo wcześniej niż sam moment zakupu i trwa także po zakończeniu transakcji (Kotler, Shalowitz, Stevens, 2011, s. 220).

Pierwszym etapem procesu jest rozpoznanie problemu, czyli uświadomienie sobie zaistnienia danej potrzeby. Potrzebę podjęcia leczenia mogą wywoływać określone bodźce: zarówno wewnętrzne, a więc stan psychofizyczny oraz podstawowe potrzeby człowieka, np. bezpieczeństwo, jak i pochodzące ze środowiska zewnętrznego, czyli pobudzane przez otoczenie pacjenta np. rodzinę, przyjaciół, lekarza, reklamę, artykuł itp. Po dostrzeżeniu potrzeby następuje kolejna faza procesu, jaką jest poszukiwanie informacji oraz poddanie ich ocenie i selekcji. Według J. Tkaczyk (2015, s. 766-768) źródła informacji o produkcie/usłudze można podzielić na dwie zasadnicze grupy:

- źródła tradycyjne (offline), takie jak np. dyskusje/opinie rodziny i przyjaciół, przekaz telewizyjny oraz radiowy, materiały drukowane, informacje od przedstawiciela firmy/sprzedawcy, bilbordy, ulotki, materiały reklamowe drukowane itp.,

- $\quad$ źródła internetowe (online), do których można zaliczyć np. strony WWW danej marki/firmy, media społecznościowe, filmy online, strony z recenzjami/opiniami klientów, fora dyskusyjne, blogi, portale aukcyjne, porównywarki cenowe, e-mail (newslettery, oferty), czasopisma online itp.

Następnym etapem w podejmowaniu decyzji zakupowych jest ocena dostępnych rozwiązań. Polega ona na porównywaniu jednego dobra z innym na podstawie oceny atrybutów. W przypadku usług medycznych kryteria oceny mogą dotyczyć samej usługi np. stosowane narzędzia, rodzaj użytej aparatury, ryzyko powikłań czy wreszcie opinia o danym świadczeniodawcy, czyli jego profesjonalizm czy fachowość. Dodatkowymi czynnikami wartościującymi mogą być: lokalizacja 
gabinetu, wygląd placówki, godziny otwarcia, formy płatności, życzliwość personelu itp. Następnie, na podstawie dokonanej analizy alternatywnych rozwiązań, następuje wybór jednej z możliwości oraz decyzja o jej zakupie. Według badań przeprowadzonych w 2011 roku przez B. Nowotarską-Romaniak w przypadku usług zdrowotnych do głównych czynników wpływających na tę decyzję można zaliczyć: stan zdrowia (97\% wskazań), zmniejszenie ryzyka zachorowań (72\%), poczucie bezpieczeństwa (48\%) oraz rozwagę (41\%) (Nowotarska-Romaniak, 2013, s. 47-48). Ostatnim etapem w omawianym procesie jest zachowanie pozakupowe, czyli odczucia towarzyszące pacjentowi po wykonaniu usługi związane ze stopniem zaspokojenia jego potrzeby. Wówczas może pojawić się również dysonans pozakupowy, który związany jest z przekonaniem pacjenta o podjęciu niewłaściwej decyzji, a co się z tym wiąże - brakiem zadowolenia z podjętego wyboru (Kieżel, 2004, s. 25). Niemniej jednak prawdopodobieństwo wystąpienia tego zjawiska warunkuje wiele czynników, np. ważność decyzji, jej nieodwracalność, czas oraz skłonność danej jednostki do niepokoju. Zatem nie zawsze tylko jakość świadczonej usługi będzie decydowała o zadowoleniu pacjenta z przebiegu leczenia.

\section{Funkcjonalność mediów społecznościowych i ich użytkownicy}

W dzisiejszych czasach siła oddziaływania internetu jest ogromna - potwierdza to fakt, że na początku 2014 roku 78\% wszystkich mieszkańców UE w wieku od 16 do 74 lat korzystało z internetu (Dane statystyczne..., 2015). Wśród różnych aktywności realizowanych w sieci coraz większą popularnością cieszą się media społecznościowe (social media). Są to aplikacje, które umożliwiają użytkownikom tworzenie i wymianę treści za pomocą blogów, forów i grup dyskusyjnych, audio i wideo komunikatorów, serwisów społecznościowych itp. Za pośrednictwem serwisów społecznościowych ich użytkownicy mogą (Mazurek, 2015, s. 93-94; Zalega, 2016, s. 206):

- uczestniczyć w badaniach online,

- weryfikować oraz oceniać dobra/usługi oraz tworzyć rankingi popularności,

- prowadzić dialog z innymi użytkownikami za pomocą komunikatorów online, blogów itp.,

- $\quad$ wypowiadać opinie, skargi, sugestie, komentarze,

- tworzyć bazy wiedzy.

Co ciekawe, użytkownicy mediów społecznościowych mogą pełnić w nich różne role. Według C.A. Bryanta można ich podzielić na sześć podstawowych grup (Zalega, 2016, s. 207): 
- bierni, którzy nie uczestniczą w kreowaniu wartości dla przedsiębiorstwa,

- obserwatorzy, czyli tacy, którzy czytają, słuchają, oglądają, śledzą, jednak nie podejmują aktywności czynnej,

- $\quad$ zwykli użytkownicy posiadający na portalach własne profile użytkowane w najprostszym, podstawowym zakresie,

- zbieracze - gromadzący informacje ułatwiające im podejmowanie własnych decyzji,

- $\quad$ krytycy, czyli użytkownicy, którzy oceniają, komentują, recenzują i biorą udział w dyskusjach i wymianie informacji,

- $\quad$ twórcy, czyli użytkownicy tworzący zawartość portali, mający wpływ na kreowanie i postrzeganie problemów przez pozostałych użytkowników.

Popularność mediów społecznościowych wynika z rozwoju technologii informatycznej - dzięki komputerom, smartfonom, tabletom czy wreszcie telefonom komórkowym niemal każdy może mieć dostęp do internetu. Zdobycie informacji o towarze czy usłudze możliwe jest więc w dowolnym miejscu i czasie. Uzyskiwane w ten sposób informacje sprzyjają dostrzeganiu nowych potrzeb oraz mają wpływ na postrzeganie dobra/usługi (Zalega, 2016, s. 206). W tym przypadku możliwe jest wykorzystanie efektu word of mouth, czyli polecenia innym internautom usług czy konkretnych osób na zasadach marketingu wirusowego. Biorąc pod uwagę usługi medyczne, w sieci wizerunek gabinetu, a właściwie lekarza, kreują także sami pacjenci, wyrażający swoje opinie na profilach typu Znanylekarz.pl, Rankinglekarzy.pl czy Dobrylekarz. pl. Na wymienionych stronach, poza opiniami na temat danego specjalisty, pacjenci mogą również przydzielać oceny, dzięki czemu tworzony jest w pewnym sensie ranking specjalistów. Zaletą takich rozwiązań jest to, że umożliwiają one komunikację dwustronną. Pacjenci mogą wyrażać swoje opinie, ale również sam specjalista może na nie odpowiadać. Oczywiście w tym wypadku lekarz nie ma bezpośredniej możliwości tworzenia recenzji (chyba że innemu specjaliście, występując w roli pacjenta), niemniej jednak może włączyć dodatkowe usługi, które zwiększą jego atrakcyjność w sieci, np. zdjęcie, kalendarz wizyt, możliwość umówienia się online itp. Ponadto może odpowiadać na komentarze wystawione przez pacjentów. Na zwiększenie oddziaływania świadczeniodawców na społeczności wirtualne mogą wpływać także: obecność na forach dyskusyjnych, własna strona internetowa czy profil w serwisach społecznościowych.

\section{Metodyka badań, charakterystyka grupy badawczej}

Celem badań była identyfikacja wpływu informacji dostępnych w sieci na decyzje zakupowe pacjentów. W tym celu przeprowadzono badania ankietowe z samodzielnie opracowanym kwestionariuszem ankiety. Badania przeprowadzono w kwietniu 
i maju 2017 roku, wśród pacjentów zakładów opieki zdrowotnej publicznych i niepublicznych funkcjonujących na terenie Lublina. Kwestionariusz wypełniło 325 pacjentów, a w związku z tym, że siedem było niekompletnych, ostatecznie do analizy przyjęto 318 ankiet. Badaną próbę scharakteryzowano na podstawie płci, wieku, wykształcenia, miejsca zamieszkania oraz sytuacji materialnej. Biorąc pod uwagę płeć, $60 \%$ respondentów stanowiły kobiety, zaś $40 \%$ mężczyźni. Pod względem kryterium wieku respondentów, przewagę liczebną stanowiły osoby do 25 . roku życia (68\%), od 26-40 lat $-22 \%$ oraz od $41-60$ lat $-10 \%$. W badanej grupie $74 \%$ osób pracuje zawodowo (często równolegle studiując), zaś $26 \%$ nie pracuje bądź tylko studiuje. $76 \%$ respondentów stanowili mieszkańcy miast, zaś $24 \%$ mieszkańcy wsi. Biorąc pod uwagę sytuację materialną, 53\% badanych określiło swoją sytuację jako dobrą, $43 \%$ przeciętną, zaś $4 \%$ jako trudną. W badanej grupie $69 \%$ posiadało wyższe wykształcenie, a 31\% wykształcenie średnie. W grupie respondentów nie było osób z wykształceniem podstawowym lub zawodowym.

\section{Internetowe zasoby informacji a zachowania nabywców usług medycznych}

Obecnie prawie każdy dorosły obywatel Polski korzysta z internetu. Popularność tego kanału informacji jest znacząca także w przypadku usług zdrowotnych, co potwierdza fakt, że $82 \%$ ankietowanych korzysta $\mathrm{z}$ informacji zawartych w sieci przy wyborze lekarza, przy czym 3\% kieruje się tymi informacjami przy każdym wyborze, zaś 53\% określa to działanie jako „dość częste”. Ponadto $61 \%$ badanych przyznaje, że chociaż raz dokonało wyboru lekarza wyłącznie na podstawie opinii dostępnych w sieci. Główne formy aktywności w internecie to bierna aktywność, np. poszukiwanie informacji o chorobach, danym lekarzu czy śledzenie rekomendacji. Działania wymagające aktywności czynnej, jak np. dodanie opinii czy udział w forach dyskusyjnych stanowiły niewielki odsetek wszystkich działań (rys. 1). Respondenci wypełniali także pole zatytułowane jako ,inne - jakie?”, gdzie pojawiały się takie odpowiedzi jak: poszukiwanie informacji o lekach, godzinach otwarcia gabinetu czy rejestracja online.

Przewagę biernego uczestnictwa pacjentów w sieci potwierdza fakt, że tylko 15\% pacjentów dodało kiedykolwiek swoją opinię na temat danego świadczeniodawcy, przy czym, co ciekawe, intensywność dodawania komentarzy jest taka sama w przypadku satysfakcjonującej usługi, jak i negatywnych doświadczeniach. Zatem w tym przypadku nie można potwierdzić jednej z głównych zasad marketingowych mówiącej o tym, że jeden zadowolony klient powie o tym kilku, zaś niezadowolony około dziesięciu osobom. Być może grupa respondentów była zbyt mała, by osiągnąć w tej kwestii rzetelne informacje, w przyszłości należałoby więc rozszerzyć grupę badawczą. 


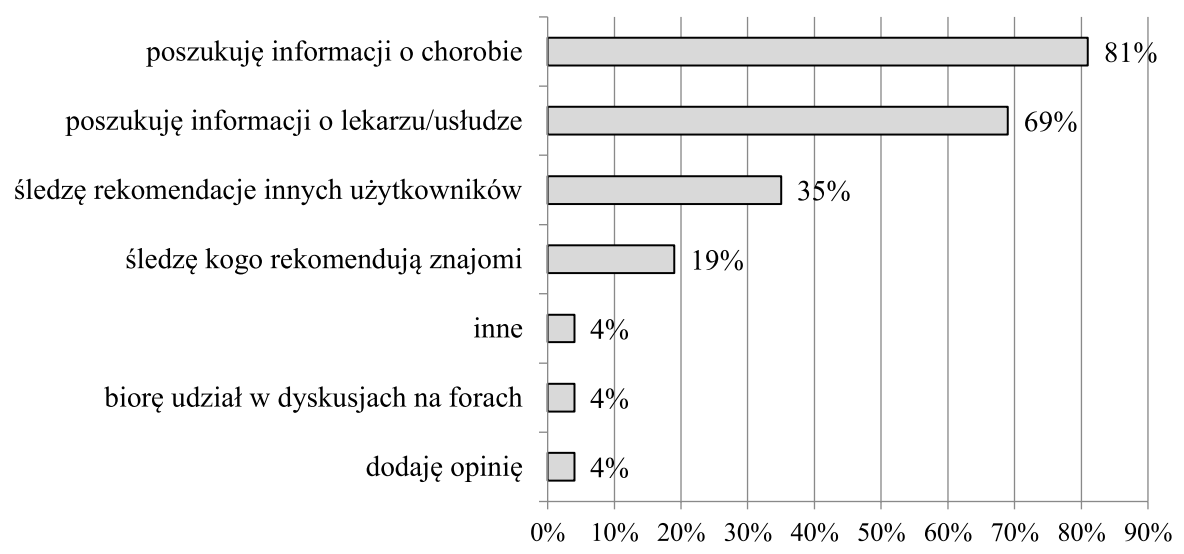

Uwaga: wyniki nie sumują się do $100 \%$, ponieważ możliwe było zaznaczenie więcej niż jednej odpowiedzi

Rysunek 1. Aktywność pacjentów w internecie

Źrodło: opracowanie własne na podstawie przeprowadzonych badań.

Kolejnym poddanym analizie zagadnieniem były witryny w internecie, w których pacjenci wyszukują informacji na temat usług medycznych. Dużą popularnością wśród respondentów cieszyły się serwisy opinii, będące głównym źródłem informacji na temat danego świadczeniodawcy (67\% wskazań) - rysunek 2. Ankietowani korzystający $\mathrm{z}$ tej formy informacji, spośród dostępnych na polskim rynku serwisów opinii najczęściej korzystali z portali: ZnanyLekarz.pl (58\%), Dobrylekarz.pl (23\%) oraz Rankinglekarzy.pl (19\%). Wymienione witryny zawierają opinie pacjentów, którzy skorzystali z usług danego świadczeniodawcy. Opinie te wyrażane są w sposób opisowy oraz punktowy, zaś ich wyszukiwanie możliwe jest przez takie zmienne, jak: nazwisko lekarza, konkretna specjalność lub miasto. Dodatkowo na podstawie wyrażonych opinii tworzone są rankingi lekarzy, w których najczęściej poza samą oceną ważna jest także liczba oddanych ocen. Warto przy tym dodać, że sami świadczeniodawcy mają wpływ (niewielki) na wygląd ich profilu. Mogą np. dodawać informacje o sobie czy o godzinach przyjęć, rejestrować pacjentów online czy wreszcie odpowiadać na pojawiające się komentarze, zwłaszcza jeśli uważają, że są krzywdzące bądź niesprawiedliwe.

Pozostałe witryny, z których korzystają pacjenci poszukując świadczeniodawcy usługi medycznej, to różnego rodzaju fora internetowe oraz portale społecznościowe. W tym przypadku użytkownicy najczęściej polecają lub odradzają danego lekarza opisując swoje doświadczenia bądź powtarzając opinie innych. W ramach portali społecznościowych konkretne osoby (często znajomi) polecają 
danego specjalistę czy placówkę. Z kolei fora internetowe najczęściej tworzone są wokół jakiegoś problemu, np. danego schorzenia. Dość sporym zainteresowaniem cieszą się również witryny poszczególnych placówek (35\% wskazań), na których pacjenci wyszukiwali głównie informacje o oferowanych usługach i ich dostępności. Ciekawą formą dzielenia się informacjami są blogi (25\% odpowiedzi), które popularne są zwłaszcza wśród pacjentów młodych - do 25 lat.

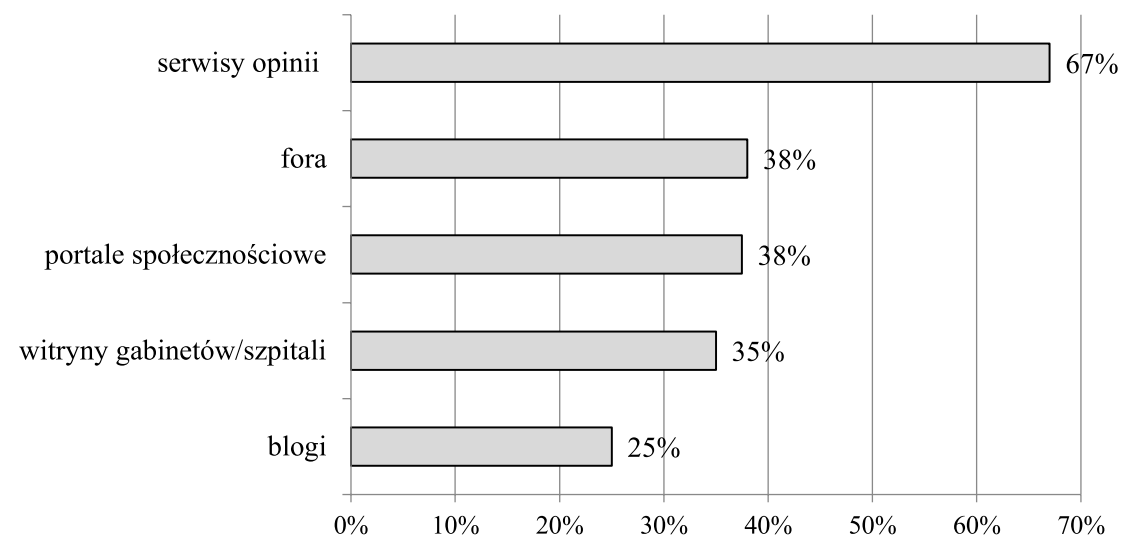

Uwaga: wyniki nie sumują się do $100 \%$, ponieważ możliwe było zaznaczenie więcej niż jednej odpowiedzi

Rysunek 2. Witryny, z których korzystają pacjenci w poszukiwaniu informacji medycznych Źródło: opracowanie własne na podstawie przeprowadzonych badań.

Siłę oddziaływania informacji dostępnych w sieci na wybór lekarza potwierdza to, że $32 \%$ badanych zrezygnowało z wyboru danego świadczeniodawcy pod wpływem tych informacji. Ponadto tylko $15 \%$ ankietowanych decyduje się na wizytę u specjalisty mimo negatywnych komentarzy, 29\% czasami rezygnuje (w zależności od wielu czynników, np. liczby komentarzy, opinii znajomych czy dostępności terminów wizyt u innych specjalistów), zaś aż 56\% wybiera innego świadczeniodawcę.

Oddziaływanie opinii zawartych $\mathrm{w}$ internecie różni się w zależności od poszukiwanej specjalności lekarskiej. Ankietowani najczęściej (78\%) wybierali w ten sposób lekarza specjalistę (najczęściej ginekologa, dermatologa, ortopedę i okulistę) oraz lekarza stomatologa (46\%). Zdecydowanie mniej (18\%) badanych poszukiwało informacji i opinii na temat lekarza rodzinnego, co może wynikać $\mathrm{z}$ tego, że w tym wypadku to dogodna lokalizacja jest głównym kryterium wyboru. 


\section{Podsumowanie}

W dzisiejszych czasach pacjenci coraz częściej korzystają z informacji zawartych z internecie. Popularność tego źródła wynika z tego, że przy wyborze placówki medycznej pacjenci kierują się przede wszystkim rekomendacjami (Jaworzyńska, Rozpędowska-Matraszek, Cholewa-Wiktor, 2017, s. 66). Wynika to z tego, że usługi medyczne należą do usług profesjonalnych, dla których podstawowym kryterium jest zaangażowanie specjalistów w proces ich realizacji. Ponadto usługa medyczna skoncentrowana jest na rozwiązywaniu problemów zdrowotnych, a pacjent najczęściej nie jest w stanie sam obiektywnie ocenić trafności podjętych działań czy wyboru wykorzystywanego sprzętu lub materiałów. Usługi profesjonalne oparte są na zaufaniu, które musi się w odbiorcy usługi wytworzyć. W przypadku braku własnych doświadczeń takim katalizatorem mogą być doświadczenia innych osób, najlepiej bliskich. Jednak uzyskanie informacji od rodziny bądź bliskich znajomych nie zawsze jest możliwe, ponieważ najbliższe otoczenie może nie mieć doświadczeń z daną jednostką chorobową. W związku z tym pacjenci coraz częściej poszukują źródeł, w których uzyskanie takich informacji byłoby możliwe. Ze względu na swój zasięg, szybkość i łatwość uzyskania danych, takim miejscem stał się właśnie internet.

Wyniki przeprowadzonych badań pozwalają stwierdzić, że zarówno dobre, jak i złe opinie innych wpływają na decyzje zakupowe pacjentów, ponieważ ponad $80 \%$ badanych chociaż raz dokonała wyboru świadczeniodawcy korzystając z informacji sieciowych, a ponad połowa - bazując wyłącznie na nich. Dlatego też zasadne wydaje się, by świadczeniodawcy nie tylko dbali o swój wizerunek za pomocą wysokiej jakości świadczonej usługi, wyrażonej w poziomie obsługi pacjenta czy jakości używanych materiałów i aparatury, ale również zadbali o swój wizerunek w sieci. Popularność tego kanału informacji sprawia, że wygląd profilu specjalisty w sieci przekłada się także na jego odbiór w realnym życiu.

\section{Bibliografia}

Dane statystyczne dotyczace spoleczeństwa informacyjnego - gospodarstwa domowe $i$ osoby indywidualne (2015). Eurostat. Pobrano z: http://ec.europa.eu/eurostat/ statistics-explained/index.php/Archive:Dane_statystyczne_dotycz\%C4\%85ce_spo$\%$ C5\%82ecze $\%$ C5\%84stwa_informacyjnego_\%E2\%80\%93_gospodarstwa_domowe_i_osoby_indywidualne.

Jaworzyńska, M., Rozpędowska-Matraszek, D., Cholewa-Wiktor, M. (2017). Zarzadzanie w stużbie zdrowia. Strategia, marketing, personel. Warszawa: Texter.

Kieżel, E. (2004). Racjonalność konsumpcji i zachowań konsumentów. Warszawa: Polskie Wydawnictwo Ekonomiczne. 
Kotler, Ph., Shalowitz, J., Stevens, R.J. (2011). Marketing strategiczny w opiece zdrowotnej. Warszawa: Oficyna a Wolters Kluwer business.

Mazurek, M. (2015). Media społecznościowe w działaniach promocyjnych narodowych organizacji turystycznych. Rozprawy Naukowe Akademii Wychowania Fizycznego we Wrocławiu, 50, 92-99.

Nowotarska-Romaniak, B. (2013). Marketing ustug zdrowotnych. Warszawa: Wolters Kluwer business.

Paszkowska, M. (2010). Kontraktowanie świadczeń zdrowotnych jako źródło finansowania zakładu opieki zdrowotnej. e-Finanse, 6 (3), 77-92.

Rudnicki, L. (2000). Zachowania konsumentów na rynku. Warszawa: Polskie Wydawnictwo Ekonomiczne.

Tkaczyk, J. (2015). Źródła informacji w procesie podejmowania decyzji o zakupie przez e-konsumentów - Polska na tle innych państw UE. Marketing i Rynek, 8, 757-770.

Zalega, T. (2016). Nowe trendy konsumenckie jako przejaw innowacyjnych zachowań współczesnych konsumentów. Nierówności Społeczne a Wzrost Gospodarczy, 46, $202-225$.

\section{Internet Information Resources and the Decisions of Medical Services Clients}

Keywords: internet information resources, medical services, purchase decisions of patients

Summary. Social media are increasingly influencing their users' decisions also as in the scope of the choice of medical services providers. Participants of social or discussion groups exchange their views and experiences by using the word of mouth, i.e. by recommending services or particular people to other internet users on the basis of the viral marketing. In addition, network users have an influence on shaping the image of the doctors and their offices by using rating sites such as Znanylekarz.pl or Rankinglekarzy.pl. The purpose of the paper is to present the results of research on the role of information available on the network in the decision-making process of purchasing medical services. The study was conducted among patients of the health care institutions in Lublin. The research included a self-developed survey questionnaire. The analysis of the results allow to state that the opinions of the internet users influence the purchase decisions of patients, as more than $80 \%$ of the respondents, at least once, chose the medical service provider using the information obtained from the internet.

Translated by Marta Cholewa-Wiktor

\section{Cytowanie}

Cholewa-Wiktor, M. (2017). Internetowe zasoby informacji a decyzje klientów usług medycznych. Marketing i Zarzadzanie, 3 (49), 211-220. 